Nevşehir Bilim ve Teknoloji Dergisi Cilt 6(1) 102-111 2017

DOI: 10.17100/nevbiltek.304473

URL: http://dx.doi.org/10.17100/nevbiltek.304473

\title{
Karayolu Üstyapılarındaki Bozulmaların Bakım Maliyetlerine Etkisi
}

\author{
Muhammed Emin Cihangir BAĞDATLI ${ }^{1, *}$, Mehmet Şükrü YILDIRIM ${ }^{2}$ \\ ${ }^{1}$ Niğde Ömer Halisdemir Üniversitesi, Mühendislik Fakültesi, Inşaat Mühendisliği Bölümü, Niğde \\ ${ }^{2}$ Namık Kemal Üniversitesi, Çorlu Mühendislik Fakültesi, İnşaat Mühendisliği Bölümü, Tekirdăg
}

Öz

Artan nüfus ve gelişen teknolojiye paralel olarak ortaya çıkan karayolu ihtiyacını karşılamak amacıyla inşa edilen esnek karayolu üstyapıların artması, bakım ve rehabilitasyon işlerinin de göz önünde tutulmasını zorunlu hale getirmiştir. Bu bağlamda, üstyapı bakım ve onarım maliyet analizleri ile ilgili bilimsel araştırmalar yapılmaktadır. Bugüne kadar karayolu üstyapısı bozulmaları ile ilgili yapılan maliyet araştırmalarında tahmin modellerine dayalı analizler gerçekleştirilmiştir. Bu çalışmada ise, yol üstyapısında oluşan bozulma örnekleri üzerinde incelemeler yapılarak maliyet analizleri yapılmıştır. Projelendirme safhasında dikkate alınan ön veriler; trafik, iklim ve bölge, malzeme ve üstyapı taban faktörlerine bağlı olarak üstyapıda etkili oldukları bozulmalar, bakım maliyetleri açısından incelenmiş̧ir. Yapılan bu çalışmada, esnek karayolu üstyapılarının projelendirme aşamasında dikkate alınan parametrelerden, üstyapı hasarlarında en etkili kriterin malzeme faktörü olduğu görülmüştür. Bununla birlikte, esnek üstyapılarda iklim ve bölge etkisiyle meydana gelen kabarma oluşumunun, karayolları bakım maliyetleri üzerinde en etkili hasar olduğu belirlenmiştir. Ayrıca, agrega cilalanması, sökülme ve büzülme çatlaklarının bakım maliyetleri üzerindeki etkisi en düşük fiziksel deformasyonlar oldukları sonucuna ulaşılmıştır.

Anahtar Kelimeler: Bakım maliyeti, Esnek kaplama, Fiziksel deformasyon, Yol üstyapısı.

\section{The Effect of Deteriorations in the Road Pavements on Maintenance Costs}

\begin{abstract}
Increasing the flexible road pavements constructed in order to meet the need for roads occurring in parallel with the growing population and developing technology have made maintenance and rehabilitation works to become mandatory to be taken into consideration. Therefore, many scientific researches related to pavement maintenance cost analysis are carried out. So far, cost analyses on preliminary estimation models have been made to do with road pavement deterioration. In this study, cost analysis is determined by examining samples of deterioration occurring on flexible road pavements. Depending on preliminary data taken into account in design phase; traffic, climate and region, material and basement of pavement factors, deformations which they effect on pavement are examined in terms of maintenance costs. As a result of this study, it is revealed the most effective one of parameters taken into account in design phase on damages of flexible pavement is material factor. However, it is determined swelling occurring on flexible pavements because of climate and region effects have been most effective damage on maintenance costs. Besides, it is concluded that physical deformations that have been least effective on maintenance costs are aggregate polished, decomposing and shrinkage cracks.
\end{abstract}

Keywords: Maintenance costs, Flexible pavement, Physical deformation, Road pavement.

*e-mail: mecbagdatli@ohu.edu.tr 


\section{Nevşehir Bilim ve Teknoloji Dergisi Cilt 6(1) 102-111 2017}

\section{Giriş}

Türkiye'de ulaştırmanın en önemli bölümünü karayolları oluşturmaktadır. Uzunluk olarak; 2 bin $155 \mathrm{~km}$ otoyol, 31 bin $106 \mathrm{~km}$ devlet yolu ve 33 bin $513 \mathrm{~km}$ il yolu olmak üzere toplam 66 bin $774 \mathrm{~km}$ karayolu ağına sahip Türkiye'nin; \%66'sini sathi kaplamalı yollar, \%29'sini asfalt betonu yollar, \%5'sını da diğer yollar oluşturmaktadır [1]. Türkiye'de mevcut karayolların büyük bölümü sathi ve asfalt betonu kaplamalar olarak esnek üstyapı şeklinde inşa edilmiştir.

Esnek üstyapılar, uzun yıllardan beri karayolu inşaatlarında uygulanan bir kaplama türüdür. Türkiye'de mevcut yatırımlar; bu konuda uzmanlaşmış ekipler, tesis ve makine sayısının yeterli olması gibi faktörler nedeniyle esnek üstyapı kaplamaları, yaygın olarak uygulanmaktadır. Ayrıca esnek üstyapı malzemesi olan bitümlü karışımlar, hızlı ve kolay inşaat imkânıyla şehir içi ve şehir dışı yollarda trafik sıkışıklığına neden olmadan, güvenli ve hızlı bir şekilde yolun trafiğe açılmasını sağlaması yönünden uygun olmaktadır. Düşük trafik yoğunluğunda, esneklik özelliğinden dolayı daha ince bir tabaka halinde uygulanabilmesi, uzun süre bağlayıcı özelliğini kaybetmemesi, içerisinde yer alan bitüm ve agreganın kısmen geri dönüştürülebilir olması gibi nedenlerden dolayı da tercih edilen bir üstyapı malzemesi olmaktadir.

Karayolu ulaştırmasında dikkate alınması gereken en önemli unsurlardan biri de ekonomidir. Türkiye'de halen inşası hızla artan esnek yol kaplamaları, taşıt sayısı ve çeşitliliğindeki artış nedeni ile ekonomik verilerin ne denli önem arz ettiğini gözler önüne sermektedir. Trafik hacmi ve buna bağlı olarak, kaplama gerilmelerindeki artış, üstyapı problemlerinin daha sık yaşanmasına ve yolların servis ömürlerinde azalmalara sebep olmaktadır. Bu durum ise ekonomik yönden büyük kayıpları beraberinde getirmektedir. Ayrıca yol yapımında kullanılan malzemelerin, beklenen performans limitinin altında kalması ve iklim-bölge şartlarının yol üzerindeki olumsuz etkileri de yolun hizmet ömrünü en aza indirgemektedir. Ekonomik ömrü içerisinde yoldan ekonomik bir şekilde faydalanmanın veya başka bir deyişle yolun hizmet ömrünü uzatmanın tek çözümü, gerekli düzeyde yeterli bakım yaparak yol üstyapısının dayanımını yükseltmektir. Bu yaklaşımla karayolunun işletimi yıllar boyunca en ekonomik düzeyde tutulmuş olacaktır. Bu kapsamda, literatürde karayolu üstyapısı bakım maliyetlerine ilişkin çok sayıda çalışma bulunmaktadır. Bu çalışmaların başlıcaları şu şekildedir:

Riggins ve ark. (1985), yaptıkları çalışmalarda, üstyapı servis yeteneği indeksi ile başlıca dört bozulma tipini kullanarak üstyapı performansı tahmin modeli geliştirmişlerdir. Ayrıca esnek üstyapı tasarımında bu yöntemin uygulaması ile ilgili bilgiler verilmiştir [2]. Carnahan ve ark. (1986), üstyapı bozulmaları için optimum bakım kararlarını elde edebilen bir yöntem geliştirmişlerdir. Bu yöntemi, beklenen bakım maliyetini minimuma indirgerken, üstyapı performans gereklerini de yerine getirebilecek şekilde tasarlamışlardır. Optimizasyon için, Markov modelini kullanmışlardır. Örnek veriler kullanarak modelin kullanılabilirliğini göstermişlerdir [3]. Markov ve ark. (1987), yol üstyapı bakımı ve rehabilitesi için dinamik kontrol kuramı geliştirmişlerdir. Bu kuramın, karayolu altyapısını yönetmek adına etkili bir yöntem olduğunu göstermişlerdir. Bu kuram, dinamik amaç fonksiyonu ve dinamik kıstaslar açısından üstyapı bakımı ve rehabilitasyonunu biçimlendirmiştir [4]. Fwa ve Sinha (1991), farklı üstyapı performans düzeylerinin maliyet hesabı için iki yaklaşım önermişlerdir. İlk yaklaşımda, çeşitli stratejilerin tüm üstyapı performansındaki farklılıklarını karşılaştırmak için, bir performans ölçümü kullanmışlardır. Diğer yaklaşımda ise, ölçülebilir yararlar ve üstyapı servis yeteneği değerleri arasında bir ilişki kurmaya 
çalışmışlardır. Yaptıkları sayısal bir örnek, ekonomik çözümleme içindeki üstyapı performans düzeyinin ömür-döngü maliyet çözümlemesinde önemli miktarda etkiye sahip olduğunu göstermiştir. Sonuç olarak, üstyapı performansı ile ekonomik çözümlemenin birleştirilmesinin farklı üstyapı stratejilerinin daha iyi değerlendirilmesini sağlayacağını belirlemişlerdir [5]. Otto ve Ariaratnam (1999), performans ölçüm sistemlerinin genel kuramlarını açıklamış ve karayolu bakımında, bu kuramların uygulamalarının örneklerinden bahsetmişlerdir [6]. Tsunokawa ve ark. (2002), üstyapı tasarım standartlarının sanayileşmiş ülkeler ile gelişmiş olan ülkeler arasında farklılık gösterdiğini belirlemişlerdir. Aynı tasarım standartlarını kullanmanın, ilk yapım maliyeti ile bakım maliyetleri arasındaki ve kuruluş maliyetleri ile kullanıcı maliyetleri arasındaki farklılıklar nedeniyle ekonomik olmadığını göstermişlerdir [7]. Kuloğlu ve ark. (2004), esnek üstyapılarda meydana gelen bozulmalara ait ayrışmalar sınıfına giren kusma olayını, yeni bir yöntem geliştirerek deneysel olarak incelemişlerdir. Sonuçta, agrega gradasyonundaki ince malzeme miktarının kusma olayında etkili olduğunu, kusma miktarı ile sıcaklık, trafik yükü ve bitüm miktarı arasında lineer bir ilişki olduğunu tespit etmişlerdir [8]. Lamptey ve ark. (2005) yol üstyapılarında optimum bakım maliyetlerinin elde edilebilmesi için INDOT tasarım standartlarını temel alarak yaşam döngü maliyet yöntemi ile bir analiz yaklaşımı geliştirmişlerdir [9]. Zhe-liang (2007) yılında yapmış olduğu bir çalışmada fayda maliyet analizini yol üstyapı koruyucu bakım stratejilerine adapte etmiştir. Şangay'da kullanılan yol kaplama bakım uygulamaları ekonomik parametrelerle değerlendirilmiştir [10]. Pratico ve ark. (2010) yapmış oldukları çalışmada yol üstyapı ömrü maliyetinin asfalt bağlayıcı kalitesine bağımlılığını modellemek ve belirli bir sınır koşulları sınıfı için bitüm viskozitesi ile maliyet arasındaki niceliksel ilişkiyi saptamayı amaçlamışlardır. Problemi teorik olarak modellemenin yanı sıra, mekanikampirik kaplama tasarım kılavuzunun kullanımı yoluyla deneyler ve simülasyonlar gerçekleştirilmiştir. Daha sonra bu etkilerin yaşam döngüsü maliyeti üzerindeki etkileri spesifik bir maliyet modeli kullanarak türetilmiştir. Sonuç olarak, asfalt bağlayıcı viskozitesinin beklenen kaplama ömrünü ve maliyetleri kuvvetli etkileyebileceğini ve dolayısıyla sözleşme ve inşaat yönetiminde dikkate alınması gerektiği sonucuna ulaşılmıştır [11].

Bu çalışmada, esnek yol üstyapılarda meydana gelen deformasyonların onarımlarına ait maliyet analizleri yapılmıştır. KGM'nin izlediği onarım metotları doğrultusunda yapılan bu maliyet analizleri sonucunda, esnek yol üstyapılarındaki fiziksel deformasyonların onarım maliyetleri ayrı ayrı belirlenmiştir. Böylece deformasyonların bakım maliyetleri üzerindeki etkileri tespit edilmesi amaçlanmıştır. Ayrıca çalışmada, projelendirme aşamasında dikkate alınan projelendirme kriterleri ile deformasyonlar arasındaki ilişkiye de yer verilmiştir.

\subsection{Esnek yol üstyapılarındaki fiziksel bozulmalar}

Esnek kaplamalı yollarda meydana gelen kusurların genel olarak nedenleri; trafik etkisi, iklim ve çevre etkisi, yapım ve dizayn hataları, malzeme hatalarının etkisi olarak sıralanmaktadır. Esnek kaplamalarda oluşan bozulmalar üç başlık halinde toparlanabilir. Bunlar; deformasyonlar, ayrışmalar, çatlamalardır.

Deformasyonlar, asfalt kaplama imalatından bir süre sonra görülen yapısal bozukluklardır. Bunlar kalıcı deformasyonlar şeklinde olup yol ekseni boyunca veya belirli kesimlerde yolun tüm kesitinde veya belirli kısımlarda bölgesel şekilde görülebilmektedir. Sürüş konforu ve emniyeti açısından 
önemli sakıncaları olan bu kusurların hizmet seviyesi düşük olduğundan dolayı, bölgesel tamir-onarım veya takviye tabakası yapılması gerekir. Deformasyonlar genellikle düşük stabiliteli bitümlü sıcak karışımların imalatından kaynaklanmaktadır. Bununla birlikte kaplama tabakalarının yetersiz sıkıştırılması, aşınma tabakasındaki aşırı filler ve bitüm kullanımı, alt tabakalarda ve zeminde aşırı hacim değişikliği olması, tabaka kalınlıklarının yetersiz oluşu, yetersiz drenaj gibi nedenlerinde deformasyon oluşunda önemli etkenlerdir. Deformasyonlar, tekerlek izi oluşumu, ondülasyon, çökme ve kabarma formunda ortaya çıkmaktadır. Bu tip hasarlar, aşınma tabakasının trafik etkisi ile küçük parçalar halinde kopma ve parçalanma şeklinde görülür. Aşınma tabakasından agrega danelerinin koparak ayrılmasından kaynaklanır.

Ayrışmalar genel olarak; yapım hataları, düşük kaliteli malzeme (kirli ve ıslak agrega kullanımı), serim sırasındaki segregasyon, homojen olmayan karışım, yetersiz ve yüksek penetrasyonlu asfalt (yetersiz adezyon) gibi nedenlerden oluşur. Ayrışmalar; kaplamanın ayrışmaya karşı düşük direncinden dolayı oluşan çanak şeklindeki çap ve derinlikteki çukurlar, aşınma tabakasııın parça veya tabaka halinde soyulması nedeniyle oluşan sökülmeler; agrega soyulması, agrega cilalanması ve asfaltın terlemesi veya kusması sonucunda ortaya çıkan kaygan yüzeyler olarak sınıflandırılmaktadır.

Çatlamalar, genellikle dingil yüklerinden ve bunların fazla tekrarından oluşurlar. Dingil yükünün kaplama tabakasında meydana getirdiği gerilmeler kaplama malzemesinin mukavemetini aştığı zaman çatlamalar oluşur. Ayrıca araçların ani hızlanma veya yavaşlamalarıyla ortaya çıkan yatay doğrultudaki kuvvetler de neden olabilir. Bu etkilerin dışında bir takım dış etkiler kendi başlarına veya trafik etkisiyle birlikte çatlaklıklara neden olabilir. Örneğin soğuk iklimli bölgelerdeki bitümlü kaplamalar, trafik yükleriyle birlikte sıcaklık değişiminden kaynaklanan gerilmelere maruz kalmaktadır. Bu gerilmelerin etkisiyle, bitümlü kaplamalarda termal çatlaklar ortaya çımaktadır [12]. Çatlamada asfaltın çekme mukavemeti en önemli rol oynar. Soğuk havalarda çekme mukavemeti artış gösterirken, yavaş yüklemelerde ise düşmektedir. Çatlamalar şu şekilde sıralanabilir; timsah sırtı çatlaklar, büzülme çatlakları, kenar çatlakları, ek yerleri (derz) çatlakları, kayma (ötelenme) çatlakları, yansıma çatlaklarıdır. Şekil 1'de esnek yol üstyapı kaplamalarındaki fiziksel bozulmalara ait bir gösterim verilmiştir.

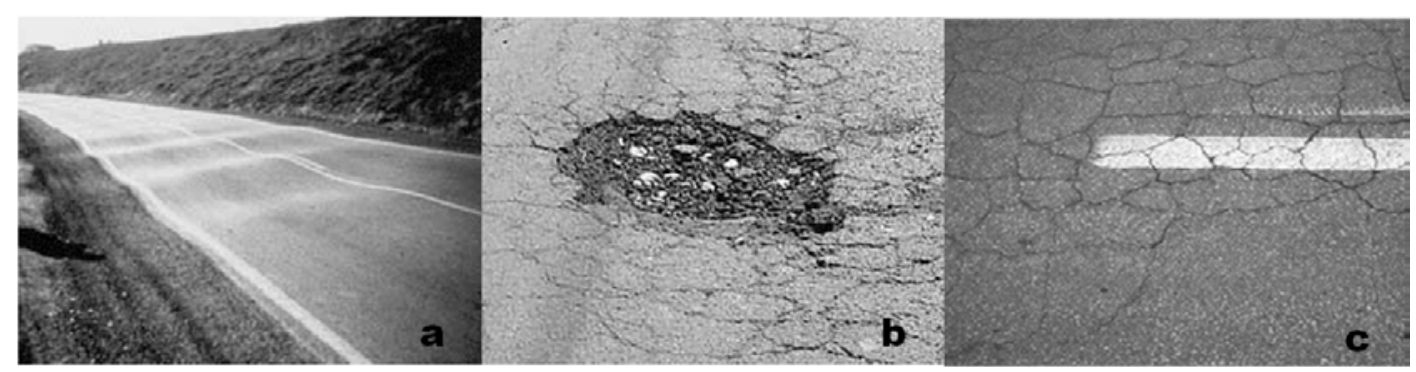

Şekil 1. a: Ondülasyon, b: Ayrışma nedeniyle oluşan yüksek şiddette bir çukur, c: Timsah sırtı çatlak

\subsection{Esnek yol üstyapı kaplamalarındaki hasar onarımları}

Yol bozulmalarının giderilmesi, nedenlerinin iyice anlaşılmasına bağlıdır. Aksi durumda nedeni hiç anlaşılamayan veya araştırılmayan bir yolun bozulan kesiminin bakım ve onarım hizmetleri, mevcut aksaklıkları gidermekten uzak kalır. Esnek yol üstyapı kaplamalarında çeşitli nedenlerle meydana gelen hasarların onarımlarına ait bilgiler aşağıda verilmiştir: 
Bölgesel yamanması; kusurlar kaplamanın belirli bölgelerinde oluşmuş ise kaplamanın tümünü söküp yeniden kaplama yapılması veya üzerine takviye tabakası yapılması yerine kusurlu bölgeler sökülüp bitümlü karışımlar ile yama yapılarak onarılmaktadır. Yamalar en yaygın olarak kullanılan bakım metotlarından biridir. Timsah sırtı çatlaklı kesimler ile çukur, lokal oturma, tekerlek izinde oturma, segregasyon ve ötelenmelerin olduğu kesimlerde yama uygulaması yapılabilir. Bölgesel yama işleminde; bozulmanın meydana geldiği kesimler düzgün bir dikdörtgen şeklinde kesilip, bozulmanın sona erdiği bitümlü tabakaya kadar kazılarak atılır. Kazıma işlemi, en alt tabakada minimum silindirleme genişliği kadar yapılır. Bu genişlik, yukarı doğru her bir tabakada bir alt tabakaya göre her yönde yarım metre arttırılarak basamaklı bir şekilde yapılmalıdır. Açılan kazı tabanı ve kazı yüzeyleri, uygun yapıştırıcı püskürtülerek aynı türden bitümlü sıcak karışım malzemeleri ile doldurulur. Sıcak karışım silindirler veya konkasörlerle sıkıştırılarak yama işlemi tamamlanır [13].

Çökmelerin onarımı; Deformasyona uğramış kesimler kazılıp atıldıktan sonra, plentmiks sıcak asfalt karışımıyla doldurulabilir. Asıl kaplamayla aynı düzeyde olacak biçimde sıkıştırılarak bu tip kusurlar kolaylıkla giderilebilir. Çökmelerin onarım işlemi sırasında hasarın olduğu bölge kazılıp temizlenerek ince bir yapıştırma tabakası tatbik edilir. Yapıştırma tabakası kürünü alınca çökmüş olan kısım bitümlü sıcak karışım ile doldurulur. Malzeme sıkıştırılarak çöken bölgenin esas kaplama ile aynı seviyeye gelmesi sağlanır. Yapılanan yama vibrasyonlu kompaktör veya silindir yardımıyla iyice sıkıştırılır. Su sızmasına mani olmak için yamanın üzerine kumlu bir koruyucu tabaka tatbik edilerek, onarım işlemi tamamlanır.

Tekerlek izi ve olukların onarımı; tekerlek izi oluşumunun nedeni belirlenmelidir. Bazı durumlarda sebep olarak teşhis edilen kaplama tabakasının sökülmesi gerekmektedir. Daha az ciddi durumlarda tekerlek izleri veya oluklar düz bir kota göre frezelenmekte veyahut da sıcak asfalt karışımı ile doldurulup ardından bir takviye tabakası örtüsü işlemi uygulanmaktadır. Oluşan oluklar, sıcak asfalt karışımıyla doldurulup tesviye edilir. Daha sonra plentmiks asfalt karışımı kullanılarak ince bir takviye tabakası inşa edilir [13].

Ondülasyon ve yığılmaların onarımı; eğer ondülelerin oluştuğu üstyapı granül bir temelle ince bir sathi kaplamadan oluşuyorsa, bozukluğu onarmak için sathı kaldırarak çıkan malzemeyi temel malzemesiyle karıştırıp sıkıştırmak gerekir. Eğer üstyapı bir bitümlü temelle 15 cm'den daha kalın bir kaplamayı içeriyorsa, fazla yüksek olmayan ondüler sıcak sıyırıcıyla düzeltilir. Daha sonra bir koruyucu tabaka veya plentmiks asfalt karışımıyla kaplanır.

Çatlakların yalıtımı ve dolgusu; çatlak genişliğinin $3 \mathrm{~mm}$ 'den küçük olması halinde bir müdahaleye gerek görülmemektedir. Fakat bu çatlakların yol yüzeyinde yaygın bir hal alması durumunda bitümlü sıcak karışım, ince yüzey kaplama veya harç tipi kaplama işlemi uygulanacaktır. Çatlak genişliği 3-20 mm arası olan enine çatlaklarda çatlak yalıtımı, boyuna çatlaklarda ise çatlak dolgusu yapılmaktadır. Çatlak genişliğinin 20 mm'den büyük olması durumunda ise harç tipi kaplama veya ince taneli bitümlü sıcak karışım malzemesi ile çatlaklar doldurulmaktadır. Yol yüzeyinin yüksek derecede timsah sırtı çatlaklarla bozulduğu, tekerlek izinde oturmaların ve taban zemininden gelen oturmaların olduğu çatlak kesimlerinde çatlak yalıtımı veya dolgu uygulaması uygulanmamalıdır. Çatlakların oluk açmaya veya istenilen şekilde doldurulmaya imkân vermeyecek şekilde s1k olması halinde, yama uygulanması yapılmaktadır [13]. 
Kabarmaların onarımı; Satıh tabakasının yerel olarak yukarıya doğru deplasmanından oluşan kabarmaların önlenmesi için, don tesirinin olmayacağı bir biçimde yol geçkisi geçirilmelidir. Ayrıca doğal zeminin uygun sıkıştırılması ve yeterli drenajın sağlanması şeklinde gerekli tedbirler alınmalıdır. Kabarma onarımları şekline göre çökme veya ondülasyon onarımı gibidir.

Sökülmelerin onarımı; asfalt kaplamalarda sökülmelerin oluşması, kaplamanın poroz hale gelmesi ve kaplamanın eskimiş ve bitümün okside olması genellikle kaplama üzerine bir sathi kaplama yapılmasını gerektiren durumlardır. Bu işlem; ara sıra onarım, kimi zamanlarda koruyucu bakım olarak uygulanır. Sathi kaplama var olan bir bozukluğu gidermek amacıyla yapılmışsa bu onarımdır. Arzu edilmeyen bir bozukluğun oluşmasını önlemek için yapılmış ise bunu koruyucu bakım işlemi saymak gerekir. Sökülmelerin onarımı sırasında bütün yabancı maddeler ve yerinden çıkmış agregalar süpürülerek yüzey temizlenir. Ardından bir karartma örtüsü uygulanır. Kaplamanın bünyesine göre su ile eşit oranda karıştırılmış asfalt emülsiyonu püskürtülür. Mevcut kaplama yüzeyinin durumuna ve trafik hacmine bağlı olarak, yol yüzeyine asfalt emülsiyonlu akıcı harç tipi koruyucu tabaka, agregalı koruyucu tabaka veya plentmiks karışım ile yapılan sathi tabakadan biri uygulanır.

Çukurların onarımı; çukurlar temizlendikten sonra, sıcak asfalt yama karışımıyla doldurularak geçici onarım işlemi yürütülür. Esaslı onarımda çukurun etrafı ve tabanı gevşememiş sağlam kısımlara kadar kesilerek temizlenir. Daha sonra çukurun temeli ve kaplama kısmı yeni malzemeyle doldurulur. Bu işlem sırasında öncelikli olarak yamanacak olan çukur, dikdörtgen şeklinde çizilerek sınırlandırılır. Çukur düşey olarak kesilerek çukurun içi temizlenir. Daha sonra çukurun temel tabakasında kalan kısmı, yeni temel malzemesi ile doldurularak sıkıştırılır. Çukurun tabanına ve yan yüzeylerine MC-30 tipi katbek bitümünden bir astar tabakası sürülerek, kürünü tamamlayıncaya kadar beklenir. Çukur 7,5 cm veya daha tabakalar halinde doldurulup, her tabaka ayrı ayrı silindirlenir. Yama yüzeyine agregalı koruyucu tabaka uygulanarak işlem tamamlanır [13].

Kaygan yüzeylerin onarımları; Terleme veya kusma bozukluğu; çoğu kez sürekli olarak sıcak kum, sıcak cüruf veya elek altı malzemesi uygulanmasıyla giderilebilir. Terlemenin veya kusmanın az olduğu durumlarda, agrega kullanılarak bir sıcak karışım yapmak veya agregalı koruyucu tabaka uygulamak yeterli bir çözüm olabilir. Bitümlü malzeme oranı düşük olan sıcak karışımla yapılan bir düzeltme tabakasında fazla bitümlü malzemeyi gidermekte yararlı olabilir. Ancak satıhta sökülmelere engel olmak için, düzeltme tabakası üzerine yeni bir aşınma tabakası yapmak gerekir. Kayma direnci azalan bir yol sathının onarımı için en iyi çözüm; sathi kaplamaya kumlu koruyucu tabaka veya agregalı koruyucu tabaka tatbik edilmesidir. Kullanılacak agrega cüruf, silisli kum veya cilalı hale gelmeyeceği denenmiş malzeme gibi dayanıklı ve aynı zamanda da dişli olmalıdır [13].

\section{Materyal ve Metot}

Karayolu esnek üstyapılarında projelendirme aşamasında bazı parametreler dikkate alınmaktadır. Bu parametreler; trafik, iklim ve bölge, malzeme ve üstyapı tabanı olarak sıralanmaktadır. Söz konusu bu parametrelerin yol üstyapısında meydana gelen fiziksel deformasyonlarla olan ilişkisini ortaya koymak ve fiziksel deformasyonların karayolu bakım maliyetleri üzerindeki etkisini araştırmak bu çalışmanın amacını oluşturmaktadır. Karayolları Genel Müdürlüğü (KGM) tarafından yol üstyapılarında yapılan 
hasar onarımları ile ilgili bakım işlemlerine ait yöntemler esas alınarak maliyet analizleri yapılmıştır. Analizlerde dikkate alınan kabuller ve kısıtlar şöyledir;

- Kaplama türleri; Bitümlü sıcak karışım kaplama ve sathi kaplamalardır.

- $\quad$ Üstyapı özellikleri; Bitümlü sıcak karışım kaplama için; Aşınma tabakası: $3 \mathrm{~cm}$, Binder: $5 \mathrm{~cm}$, Temel tabakası ve cinsi: $15 \mathrm{~cm}$ plentmiks temel, Alt Temel tabakası ve cinsi: $20 \mathrm{~cm}$ granüler alt temeldir. Sathi kaplama için; Yüzey (satıh) tabakası: $2 \mathrm{~cm}$, Temel tabakası ve cinsi: $20 \mathrm{~cm}$ granüler temeldir.

- $\quad$ Üstyapı hasarları; Kabarma, çökme, ondülasyon, tekerlek izi oluşumu, çukur, sökülme, agrega soyulması, agrega cilalanması, kenar çatlakları, kayma (öteleme) çatlakları, yansıma çatlakları, ek yer çatlakları, büzülme çatlakları, timsah sırtı çatlaklarıdır.

- Lokal hasar özellikleri; Ebatları: $1 \mathrm{~m}$ (en) x $1 \mathrm{~m}$ (boy), Alan: $1 \mathrm{~m}^{2}$ dır. Derinlikler: Hasar türü ve özelliğine bağlı olarak $2 \mathrm{~cm}, 5 \mathrm{~cm}$ ve $8 \mathrm{~cm}$ alınmıştır.

- Hasar onarımları, fiziksel deformasyonun cinsine bağlı olarak esaslı onarım olarak yapıldığı kabul edilmiştir.

Yapılan kabuller doğrultusunda, karayolu üstyapısında meydana gelen fiziksel deformasyonların onarımları, KGM Bakım Dairesi Başkanlığı onarım metotları doğrultusunda yapıldığı kabul edilerek her bir fiziksel deformasyon için birim bakım-onarım maliyet analizleri yapılmıştır. Maliyet analizlerinde kullanılan tüm birim fiyatlar Program ve İzleme Dairesi Başkanlığı Keşif ve Şartname Şubesi Müdürlüğü 2010 yılı yol, köprü, bitümlü kaplamalar, bakım ve trafik işlerine ait birim fiyat listesine göre belirlenmiştir [14].

\section{Araştırma Bulguları}

Bu çalışmada, yol üstyapılarında meydana gelen fiziksel deformasyonların onarımlarına ilişkin maliyetler incelenmiştir. Bu doğrultuda karayolu esnek üstyapı kaplamaları için söz konusu olan her bir deformasyon onarımlarına ait maliyet analizleri gerçekleştirilmiştir. Maliyet analizleri yapılırken, ön görülen kabuller kapsamında ele alınan fiziksel deformasyon örneklerinin, KGM'nin bakım ve onarım metotları doğrultusunda imalatlarının gerçekleştirildiği kabul edilmiştir. Yapılan maliyet analizlerine ait örnek bir hesaplama Tablo 1'de gösterilmiştir.

Tablo 1. Bitümlü sıcak karışım kaplamalarda çukur oluşumunun onarımına ait maliyet hesaplaması

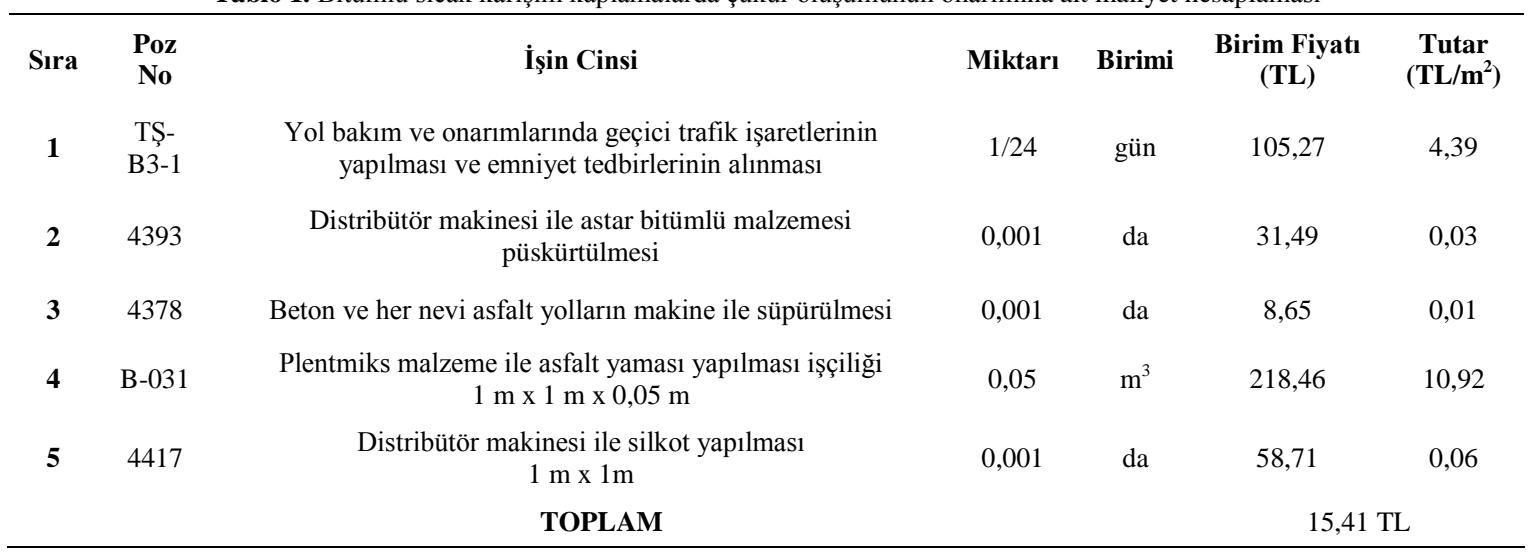


Tablo 1'de Esnek üstyapılarda malzeme faktörü etkisiyle meydana gelen çukur oluşumunun onarımına ait maliyet hesaplaması verilmiştir. Hasarın üstyapıdaki derinliği $5 \mathrm{~cm}$ alınmıştır. Çukur oluşumuna ait $1 \mathrm{~m}$ (en) x $1 \mathrm{~m}$ (boy) boyutlarındaki örnek bir hasarın onarımı ve maliyetleri esas alınmış olup, çukur oluşumunun birim maliyeti 15,41 TL olarak hesaplanmıştır. Maliyetin hesaplanmasında, hasarın bulunduğu bölge kesilerek distribütör makinesi yardımıyla astarın püskürtüldüğü, daha sonra makine yardımıyla süpürülüp temizlenerek kopan parçalar uzaklaştırıldığı, kopan parçalardan temizlenen bölgeye bitümlü yapıştırıcı uygulanarak plentmiks malzemesi döküldüğü ve serilen malzeme sıkıştırılarak hasarın onarımı yapılmış olduğu dikkate alınmıştır. Yapılan yama işçiliğine plentmiks sıcak karışım malzemesi, yapıştırıcı, bitüm malzemesi ve distribütör ve sıkıştırma fiyatları dahildir.

Yapılan tüm maliyet analizleri sonucunda esnek yol üstyapı kaplamalarında meydana gelen bozulmalardan maliyeti en yüksek olanı kabarmadır. Donma ve çözülme sonucu ortaya çıkan bu bozulma türünde etkin olan faktör, iklim ve bölge şartlarıdır. Sathi ve bitümlü sıcak karışım kaplamalarda farklı onarım metotlarıyla rehabilite edilen kabarma oluşumunun 2010 yılı birim bakım maliyeti sathi kaplamalar için 21,77 TL; bitümlü sıcak karışım kaplamalar için 21,93 TL olarak hesaplanmıştır. Esnek üstyapılarda meydana gelen fiziksel deformasyon onarımlarında en düşük bakım maliyetleri malzeme faktörü etkisiyle oluşan agrega cilalanması, sökülme ve üstyapı taban ve malzeme faktörleri etkisiyle oluşan büzülme çatlakları olduğu sonucuna ulaşılmıştır. Esnek yol üstyapı kaplamalarında meydana gelen bozulmaların onarımlarına ait gerçekleştirilen tüm maliyet analiz sonuçları Tablo 2'de verilmiştir.

Tablo 2. Esnek yol üstyapı kaplamalarındaki bozulmaların bakım-onarım maliyetleri

\begin{tabular}{|c|c|c|c|c|c|}
\hline \multirow[b]{2}{*}{$\begin{array}{l}\text { Esnek Üstyapı } \\
\text { Bozulmaları }\end{array}$} & \multicolumn{4}{|c|}{ Projelendirme Kriterleri } & \multirow[b]{2}{*}{$\begin{array}{c}\text { Bakım-Onarım } \\
\text { Maliyeti } \\
\left(\mathrm{TL} / \mathbf{m}^{2}\right)\end{array}$} \\
\hline & Trafik & $\begin{array}{l}\text { İklim ve } \\
\text { Bölge }\end{array}$ & Malzeme & $\begin{array}{l}\text { Üstyapı } \\
\text { Tabanı }\end{array}$ & \\
\hline Kabarma & & $\checkmark$ & & & 21,77 - 21,93 \\
\hline Çökme & & $\checkmark$ & $\checkmark$ & $\checkmark$ & 15,37 \\
\hline Ondülasyon & $\checkmark$ & & $\checkmark$ & & $15,37-21,77$ \\
\hline Tekerlek izi oluşumu & $\checkmark$ & & & & 15,37 \\
\hline Çukur & & & $\checkmark$ & & 15,41 \\
\hline Kusma & & & $\checkmark$ & & 5,26 \\
\hline Sökülme & & & $\checkmark$ & & 4,49 \\
\hline Agrega soyulması & & & $\checkmark$ & & 5,69 \\
\hline Agrega cilalanması & & & $\checkmark$ & & 4,45 \\
\hline Yansıma çatlakları & $\checkmark$ & $\checkmark$ & & & 21,60 \\
\hline Büzülme çatlakları & & & $\checkmark$ & $\checkmark$ & 4,49 \\
\hline Ek yer çatlakları & & & $\checkmark$ & & 21,60 \\
\hline Kenar çatlakları & $\checkmark$ & & $\checkmark$ & & 8,80 \\
\hline Kayma çatlakları & $\checkmark$ & & & & 8,78 \\
\hline Timsah sırtı çatlaklar & & & & $\checkmark$ & $7,85-21,93$ \\
\hline
\end{tabular}

Yapılan maliyet analizlerine ilişkin grafiksel sonuçlar Şekil 2'de verilmiştir. Bu grafikler incelendiğinde; esnek üstyapılardaki fiziksel deformasyonların hasar alanı artışı ile bakım maliyetlerindeki değişimleri Şekil 2'deki gibidir. Grafikler, yol üstyapısı bozulmaları ile projelendirme kriterlerinde esas alınan faktörler ilişkilendirilerek sunulmuştur. Karayolu üstyapı hasarlarının tamamına yakınının oluşumunda malzeme faktörünün etkili olduğu görülmektedir. 


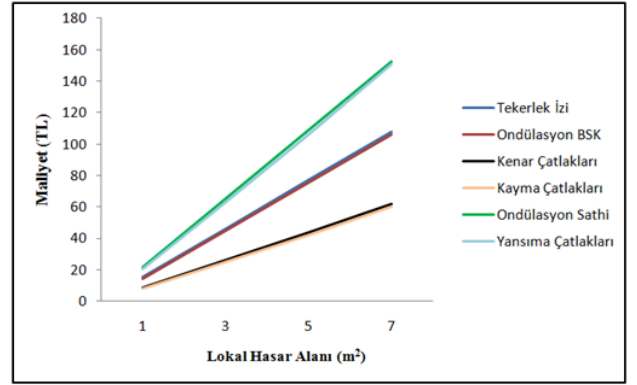

a. Trafik etkisi

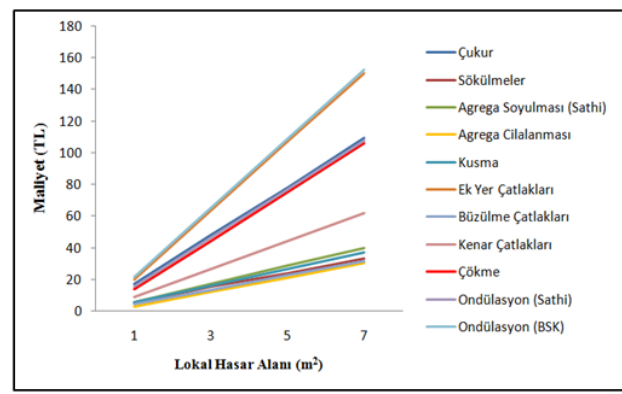

c. Malzeme etkisi

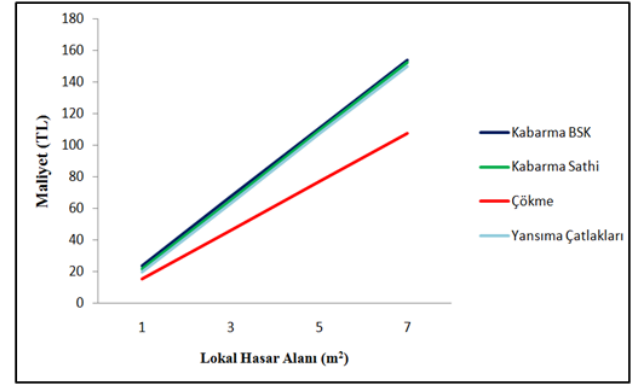

b. İklim ve bölge etkisi

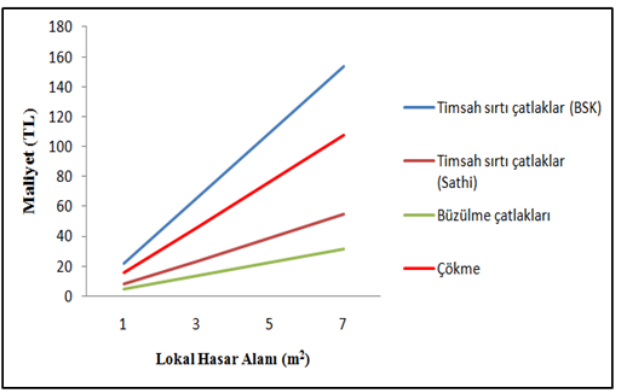

d. Üstyapı taban etkisi

Şekil 2. Bozulmaların bakım-onarım maliyetleri

\section{Sonuç ve Tartışma}

Karayolu mühendisliği ekonomisinde ilk yapım maliyetleri kadar hizmet ömrü boyunca karşılaşılacak bakım maliyetleri de önemli bir yere sahiptir. Bu bağlamda karayolu bakım maliyetlerine ve stratejilerine ilişkin literatürde çok sayıda çalışma yapılmıştır. Yapılan çalışmaların çoğunluğu performans tahmini ile maliyet ilişkilendirmesi kapsamında yer almaktadır. Bu çalışmada ise konu daha basit bir kapsamda ele alınmış olup her bir üstyapı deformasyonu örneği için maliyet hesaplamaları yapılmıştır. KGM'nin yol bakım esasları çerçevesinde izlenen adımlar takip edilerek her bir bozulma formunun birim maliyetleri elde edilmiştir. Bu yaklaşımla hem her bir bozulmanın bakım-onarım birim maliyeti ortaya konulmuş hem de bozulmaların bakım-onarım maliyetleri arasındaki ilişkiler görülmüştür. Bununla birlikte, bu çalışma kapsamında yol üstyapı projelendirme safhasında projelendirme kriteri olarak dikkate alınan faktörlerin bozulmalarla olan ilişsisine de değerlendirmeler içinde yer verilmiştir.

Lokal hasarlarda yapılan tüm onarımlar, Karayolları Genel Müdürlüğü Bakım Dairesi Başkanlığı karayolu onarım metotlarına göre; kullanılan tüm birim fiyatlar ise Program ve İzleme Dairesi Başkanlığı Keşif ve Şartname Şubesi Müdürlüğü yol, köprü, bitümlü kaplamalar, bakım ve trafik işlerine ait birim fiyat listesine göre belirlenmiştir. Maliyet analizleri sonucunda ortaya çıkan bakım maliyetleri; üstyapı kalınlığı, deformasyon derecesi ve onarımın esaslı veya geçici olarak yapılmasına göre değişiklik gösterecektir. Bu çalışmada, fiziksel deformasyonların tamamının yüksek derecede hasarlı olduğu göz önünde tutulmaya çalışılarak esaslı onarım sonucu bakım maliyetleri belirlenmiştir. Ayrıca her bir projelendirme kriterinin bakım maliyetleri üzerindeki etkisi ayrı ayrı olarak incelenmiştir. İleriki çalışmalarda hasar onarımının Karayolları Genel Müdürlüğü tarafından belirlenen deformasyon derecelendirmeleri göz önünde bulundurularak bakım maliyet aralıklarının tespit edilmesi ve üstyapı fiziksel deformasyonlarındaki her bir hasar onarımının bakım maliyet sınırlarının belirlenmesi konunun genişletilmesi açısından uygun olacağı düşünülmektedir. 


\section{Kaynaklar}

[1] KGM, “Devlet ve İl Yolları Envanteri”. Karayolları Genel Müdürlüğü www.kgm.gov.tr (erişim tarihi, 15.03.2017).

[2] Riggins M., Lytton R., L., Garcia-Diaz A., "Developing Stochastic Flexible Pavement Distress and Serviceability Equations (No. 1048)”, 1985.

[3] Carnahan J., V., Davis W., J., Shahin M., Y., Keane, P., L., Wu, M., I., “Optimal Maintenance Decisions for Pavement Management.” ASCE Journal of Transportation Engineering. Vol. 113, No. 5, pp. 554-572, 1986.

[4] Markov M., J., Brademeyer B., D., Sherwood J., Kenis W., J., “The Economic Optimization of Pavement Maintenance and Rehabilitation Policy”, Proc. of Second North American Conf. on Managing Pavements, pp. 170-182, Canada, 1987.

[5] Fwa T., F., Sinha K., C., "Pavement Performance and Life-Cycle Cost Analysis”, ASCE Journal of Transportation Engineering, Vol. 117, No. 1, pp. 33-45, 1991.

[6] Otto S., Ariaratnam S., T., "Guidelines for Developing Performance Measures in Highway Maintenance Operations”, ASCE Journal of Transportation Engineering, 125 (1) 46-54, 1999.

[7] Tsunokawa K., Islam R., Changyu G., “Optimal Strategies For Highway Pavement Management in Developing Countries”, Computer-Aided Civil and Infrastructure Engineering, Vol. 17, pp. 194-202, 2002.

[8] Kuloğlu N., Kök B., V., Öndaş M., “Sathi Kaplamalarda Kusma Olayına Etki Eden Faktörler”. 4.Ulusal Asfalt Sempozyumu, Ankara, 2004.

[9] Lamptey G., Ahmad, M., Z., Labi, S., Sinha, K., C., "Life Cycle Cost Analysis for INDOT Pavement Design Procedures”, 2005.

[10] Zhe-liang L., I., "Pavement Preventive Maintenance for Highway Based on Cost-Benefit Analysis” Journal of Highway and Transportation Research and Development, 12, 006, 2007.

[11] Praticò F., G., Casciano A., Tramontana D., "Pavement Life-Cycle Cost and Asphalt Binder Quality: Theoretical and Experimental Investigation”. Journal of Construction Engineering and Management, 137(2), 99-107, 2010.

[12] Taşdemir Y., Ağar E., “Bitümlü Kaplamalarda Düşük Sıcaklık Çatlaklarının İncelenmesi”. Itï dergisi/d mühendislik, cilt: 4, say1: 1, 59-70, 2005.

[13] KGM, “Karayolu Bakım El Kitabı”. Karayolları Genel Müdürlüğü, Bakım Dairesi Başkanlığı, Ankara, 1998.

[14] KGM, "Yol, Köprü, Bitümlü Kaplamalar, Bakım ve Trafik İşlerine Ait Birim Fiyat Listesi”, Karayolları Genel Müdürlüğü, Program ve İzleme Dairesi Başkanlığı Keşif ve Şartname Şubesi Müdürlüğü, Ankara, 2010. 